\title{
Strategi Meningkatkan Minat Beli Produk Hijau Sektor Fast Moving Consumer Goods Melalui Persepsi Nilai, \\ Risiko dan Kepercayaan
}

Rizka Zulfikar, S.Tp, MM"1 Prihatini Ade Mayvita, SE, MM²

11 rizkazulfikar @gmail.com, 21 ademayvita @egmail.com

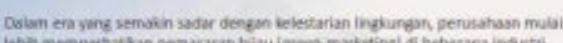

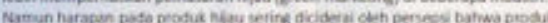

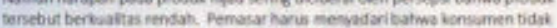

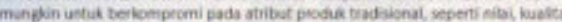

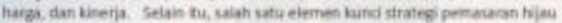
asdin bed bera:

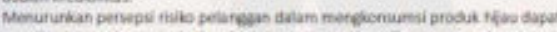

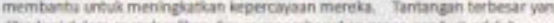

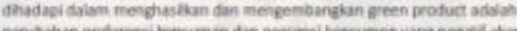

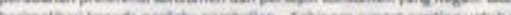

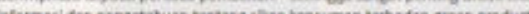

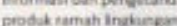

\section{Tujuan}

- Mendapattan garrbarantertans peneruh dan meded varg mentiokison tubingan antas

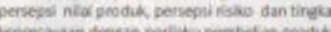

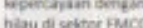

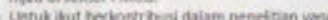

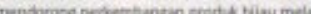

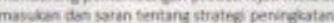

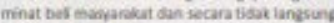

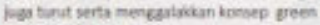
economs dimasyoraket

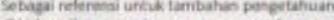

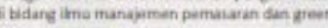

\section{Metode}
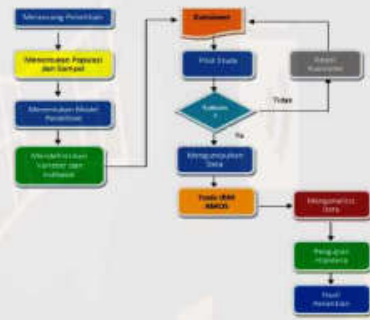

Penelitian dilaksanakan

Agustus - Oktober 2017

Banjarmasin

sovin

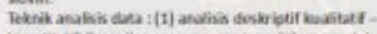

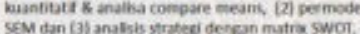
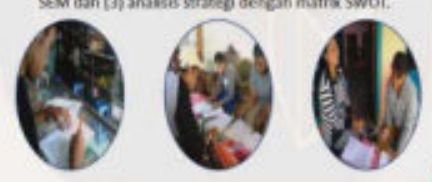

\section{8}




\section{Daftar Pustaka :}

Zulfikar, R., \& Mayvita, P. A. (2017, December). Tingkat Kepercayaan dan Minat Beli Masyarakat Banjarmasin Terhadap Produk Hijau Berdasarkan Segmentasi Demografis. In Proceeding of National Conference on Asbis (Vol. 2, No. 1, pp. 410-426).

Zulfikar, R., \& Mayvita, P. A. (2018). The Relationship of Perceived Value, Perceived Risk, and Level of Trust Towards Green Products of Fast Moving Consumer Goods Purchase Intention. JEMA: Jurnal Ilmiah Bidang Akuntansi dan Manajemen, 15(2), 1-14.

Zulfikar, R., \& Banjarmasin, U. I. K. M. The Structural Equation Models of Environmental Concern and Knowledge To Green Trust and Green Purchase Intention Towards Green Products (Guideliness).

Zulfikar, R., \& Mayvita, P. A. (2019). Does Green Economy Video Really Work? The Effectiveness of Using Video Content Marketing in Forming MSMEs Perception and Behavior to Implement Green Economy. JEMA: Jurnal Ilmiah Bidang Akuntansi dan Manajemen, 16(1), 34-45.ar

Zulfikar, R., \& Mayvita, P. A. (2019). DIVERSIFIKASI PRODUK OLAHAN BERBASIS IKAN PATIN SEBAGAI POTENSI USAHA BAGI PANTI ASUHAN AL AMIN DAN SULTAN SURIANSYAH BANJARMASIN. JURNAL PENGABDIAN AL-IKHLAS UNIVERSITAS ISLAM KALIMANTAN MUHAMMAD ARSYAD AL BANJARY, 4(1). 